\title{
Urban expansion in the Atlantic Forest: applying the Nature Futures Framework to develop a conceptual model and future scenarios
}

\author{
Rafael Cavalcanti Lembi ${ }^{1 * \mathbb{D}}$, Cecilia Cronemberger ${ }^{2,3} \mathbb{D}$, Caroline Picharillo ${ }^{4}$, Sheina Koffler ${ }^{5}$, Pedro H.

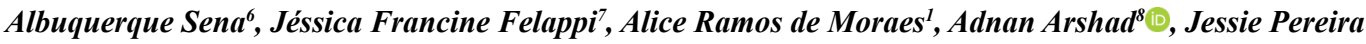 \\ dos Santos ${ }^{I}$ \& Andressa Vianna Mansur ${ }^{9}$ \\ ${ }^{1}$ Universidade Estadual de Campinas, Programa de Pós-graduação em Ecologia, Instituto de Biologia, Caixa \\ Postal 6109, 13083-970, Campinas, SP, Brasil. \\ ${ }_{2}^{2}$ Parque Nacional da Serra dos Órgãos, Instituto Chico Mendes de Conservação da Biodiversidade, Av. \\ Rotariana s/n, 25960-602, Teresópolis, RJ, Brasil. \\ ${ }^{3}$ Universidade do Estado do Rio de Janeiro, Programa de Pós-Graduação em Meio Ambiente, Rua São \\ Francisco Xavier 524, 20550-900, Rio de Janeiro, RJ, Brasil. \\ ${ }^{4}$ Universidade de São Paulo, Escola de Engenharia de São Carlos, Avenida Trabalhador São-Carlense, 400, \\ 13566-590, São Carlos, SP, Brasil. \\ ${ }^{5}$ Universidade de São Paulo, Instituto de Estudos Avançados, Rua da Praça do Relógio, 109, 05508-050, São \\ Paulo, SP, Brasil. \\ ${ }^{6}$ Universidade Federal de Pernambuco, Centro de Biociências, Departamento de Botânica, Av. da Engenharia, \\ Cidade Universitária, 52171-011, Recife, PE, Brasil. \\ ${ }^{7}$ University of Bonn, Center for Development Research, Genscherallee 3, 53113, Bonn, Germany. \\ ${ }^{8}$ China Agricultural University, College of Resources and Environmental Sciences, Beijing 100193 P.R. China. \\ ${ }^{9}$ German Centre for Integrative Biodiversity Research (iDiv) Halle-Jena-Leipzig, Deutscher Platz 5E, 04103, \\ Leipzig, Germany. \\ *Corresponding author: Rafael CavalcantiLembi,e-mail:rclembi@gmail.com
}

Lembi, R.C., Cronemberger, C., Picharillo, C., Koffler, S., Sena, P.H.A., Felappi, J.F., Moraes, A.R., Arshad, A., Santos, J.P., Mansur, A.V. Urban expansion in the Atlantic Forest: applying the Nature Futures Framework to develop a conceptual model and future scenarios. Biota Neotropica 20(suppl. 1): e20190904. https://doi.org/10.1590/1676-0611-BN-2019-0904

\begin{abstract}
The Atlantic Forest is an important hotspot of biodiversity and ecosystem services that contributes to the well-being of its 125 million human inhabitants, about three quarters of the Brazilian population. In the coming decades, forecasts show that urban areas in the Atlantic Forest will grow at the expense of natural ecosystems, leading to increasing pressure on biodiversity and ecosystem services. We used the Nature Futures Framework (NFF) for envisioning positive scenarios for cities in the Atlantic Forest. First, we developed a conceptual model based on the Driver-Pressure-State-Impact-Response (DPSIR) approach to describe consequences of urban growth for the three NFF perspectives: Nature for Society, Nature for Nature and Nature as Culture. Second, we proposed scenario storylines that encompass multiple social-ecological values of nature and could be used by policy makers to plan desirable futures for the Atlantic Forest. Then, we discussed the impact of distinct policies on these values, identifying the different ways in which the management of urban green and blue spaces, natural ecosystems, and urban densities can lead to different social-ecological outcomes. We further detail the complexity, trade-offs, and synergies regarding city development, nature conservation, and human well-being in this tropical hotspot. Applying NFF can contribute to the ongoing debate regarding urban sustainability, by providing an interdisciplinary and integrative approach that explicitly incorporates multiple values of nature and the visualization of positive futures. Keywords: Biodiversity; Ecosystem Services; Human well-being; Urban planning; Connectivity.
\end{abstract}

\section{Expansão urbana na Mata Atlântica: aplicando o "Nature Futures Framework" para desenvolver um modelo conceitual e cenários futuros}

Resumo: A Mata Atlântica é um importante hotspot de biodiversidade e serviços ecossistêmicos que contribui para o bem-estar de seus 125 milhões de habitantes, cerca de três quartos da população brasileira. Nas próximas décadas, a previsão é de que as áreas urbanas na Mata Atlântica crescerão às custas de ecossistemas naturais, conduzindo a um aumento na pressão sobre a biodiversidade e os serviços ecossistêmicos. Nós usamos a perspectiva do Nature 
Futures Framework (NFF) para visualizar cenários positivos para as cidades na Mata Atlântica. Em primeiro lugar, desenvolvemos um modelo conceitual baseado na abordagem Driver-Pressure-State-Impact-Response (DPSIR) para descrever as consequências do crescimento urbano para as três perspectivas do NFF: Natureza para a Sociedade, Natureza para a Natureza, e Natureza como Cultura. Em seguida, propusemos cenários na forma de narrativas que abrangem múltiplos valores socioecológicos para a natureza, e que pudessem ser usados por tomadores de decisão para planejar futuros desejáveis para a Mata Atlântica. Posteriormente, discutimos os impactos de distintas políticas sob esses valores, identificando como diferentes maneiras de gerenciar os espaços urbanos verdes e azuis, os ecossistemas naturais, e as densidades urbanas podem conduzir a diferentes contextos socioecológicos. Ainda, nós detalhamos a complexidade, os trade-offs e as sinergias relacionados ao desenvolvimento de cidades, conservação da natureza e bem-estar humano neste hotspot tropical. A aplicação do NFF pode contribuir para o debate em andamento sobre sustentabilidade urbana, por meio do fornecimento de uma abordagem interdisciplinar e integrativa que explicitamente incorpora múltiplos valores da natureza e a visualização de futuros positivos.

Palavras-chave: Biodiversidade; Serviços ecossistêmicos; Bem-estar humano; Planejamento urbano; Conectividade.

\section{Introduction}

Brazil is a highly urbanized country - $90 \%$ of the gross domestic product (GDP) is created in cities, which harbour approximately $80 \%$ of the country's population (DaMata et al. 2007), mostly located in the Atlantic Forest Domain (Cincotta et al. 2000). This biodiversity hotspot originally covered about $17 \%$ of the country's territory and most of its coastal area, and nowadays the region is responsible for $70 \%$ of the GDP, $2 / 3$ of the industrial economy, and is home to more than 125 million Brazilians (Rezende et al. 2018, Joly et al. 2014). This biome is already severely affected by human activities - only $28 \%$ of its original vegetation remains, $30 \%$ of which is inside protected areas (Rezende et al. 2018). Pressures are likely to increase: estimates by the UN Population Division for Brazil indicate that $92 \%$ of the population will live in cities by 2050, and the total urban population will be over 215 million (UN 2019). In the Atlantic Forest specifically, a 160\% increase in urban area is predicted from 2000 to 2030 (Seto et al. 2012). Besides, it is likely that more than $20 \%$ of the expansion of cities located along the Atlantic coast of Brazil will occur within areas currently supporting natural habitats (McDonald et al. 2018a), turning it into one of the most affected regions of the world in terms of natural habitat and biodiversity loss due to urban growth (McDonald et al. 2018b).

Although most of the Atlantic Forest has been converted to other uses (Rezende et al. 2018), forest remnants still provide important biodiversity and ecosystem services to about three quarters of the Brazilian population, such as water supply for human use and power generation; food and feed; climate regulation; protection against floods and landslides; pollination; and cultural services such as supporting identities of traditional peoples and providing recreational opportunities (Joly et al. 2014). However, human activities such as the conversion of forest in urban spaces, crop areas, and industrial uses threaten the quantity and quality of biodiversity and ecosystem services provided by the Atlantic Forest (Ditt et al. 2010).

Many studies target the impact of urban expansion on natural habitats (Seto et al. 2011, Seto et al. 2012, Guneralp and Seto 2013; McDonald et al. 2018a, 2018b). Limiting the sprawl as well as planning the spatial pattern of urbanization is important to minimize the impacts on ecosystems (UNCCD 2017) since the negative impacts of urban expansion transcend the limits of cities. In tropical forests, for instance, it may increase habitat fragmentation, decrease biodiversity (Fahrig 2003), and potentially hamper the delivery of ecosystem services provided by forests (Mitchell et al. 2014). In parallel, there can be significant impacts inside cities as well, such as the intensification of urban heat islands and human well-being impairment (Krüger et al. 2011). Unplanned or inadequately managed urban growth may result in uneven access of city dwellers to biodiversity and ecosystem services provided by the Atlantic Forest (Krüger et al. 2011). In contrast, well-planned urbanization informed by an understanding of population trends, climate change, and biodiversity scenarios can help maximize benefits while minimizing environmental degradation (UN 2019).

The coupled nature of societal and environmental dimensions regarding urban expansion in the Atlantic Forest requires a socialecological systems approach, which recognizes people as part of nature, as well as considers the complexity and uncertainty that emerge in those systems (Berkes \& Folke 1998). Therefore, interdisciplinary tools to navigate this complexity are needed and models and scenarios can be useful in this regard. Models are qualitative or quantitative descriptions of key components of a given system and the relationships between those components. Scenarios are representations of possible futures for one or more components of a system (IPBES 2016). Models and scenarios can contribute to policy making by addressing relationships and feedbacks between environmental drivers, biodiversity and ecosystem services, and socioeconomic dynamics (Pereira et al. 2010).

It is important to stress that although urban growth affects biodiversity and ecosystem services in the Atlantic Forest, those impacts are not perceived in the same way by different stakeholders. People differ in how they value nature depending on local, cultural, socioeconomic, and ecological contexts, and the recognition of this plurality of values can improve policy-making by practitioners (González-Jiménez et al. 2018). Pascual et al. (2017) and Díaz et al. (2018) recognized those differences and proposed assigned values to nature that can be intrinsic, instrumental, or relational. In parallel, the concept of Nature's Contributions to People (NCP) has been introduced within the Intergovernmental Platform on Biodiversity and Ecosystem Services (IPBES) as a more comprehensive way to address ecosystem services, while taking into account all contributions of living nature for people's quality of life and the cultural context present in all naturesociety relationships (Díaz et al. 2018).

More recently, new frameworks to assess the impacts of changes in biodiversity and ecosystem services considering different worldviews have been proposed, such as the Nature Futures Framework (NFF), which was developed by IPBES as a strategy to formulate scenarios 
centred on our relationship with nature to inform decision-making at multiple scales (PBL 2018, Rosa et al. 2017). NFF can be used to model impacts of drivers and policy responses while recognising multiple dimensions of three perspectives of nature: Nature for Nature, Nature for Society, and Nature as Culture. In Nature for Nature, nature is regarded as having a value in and of itself without human intervention, and the preservation of nature's diversity and functions is of primary importance; Nature for Society relates to nature being primarily valued for the benefits or uses people derive from it, which could lead to an optimisation of multiple uses of nature; Nature as Culture considers humans as an integral part of nature and its functions (PBL 2018). These three perspectives form a continuum, or gradient, that is represented by a triangular framework, which can be viewed across different scales and sectors (Figure 1). The process of applying NFF to develop possible futures for nature produces multiple, stakeholder-defined endpoints. Once alternative nature futures are identified, qualitative and quantitative approaches (for example, modelling, empirical studies, and expert knowledge) can be used to identify potential pathways for reaching these endpoints, including specific policy alternatives and feedbacks between biodiversity and ecosystem services, human wellbeing, and decision-making (Rosa et al. 2017).

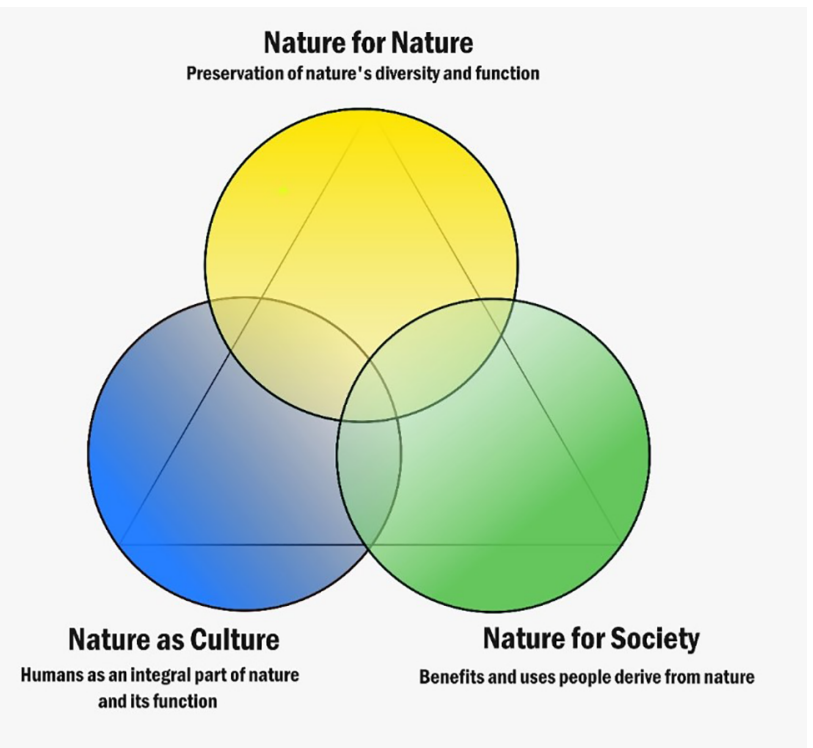

Figure 1. Conceptual framework of the Nature Futures Framework (Adapted from PBL 2018).

This paper is the result of a group exercise from the São Paulo School of Advanced Science on Scenarios and Modelling in Biodiversity and Ecosystem Services to Support Human Well-Being (SPSAS Scenarios), a 120-hour course developed by the Brazilian Platform on Biodiversity and Ecosystem Services (BPBES) and funded by the São Paulo Research Foundation (FAPESP) in July 2019. We aimed to (i) develop a conceptual model describing drivers and impacts of urban growth in the Brazilian Atlantic Forest, considering the complex relationship between nature and people by employing the NFF; (ii) propose three nature future scenarios for urban expansion, analyze and compare the impact of distinct policies on multiple social-ecological values of nature. We do not intend to thoroughly debate the issues involved, but instead to contribute to developing a better understanding and appreciation of the complexities, trade-offs, and synergies which need to be considered in reconciling city development, nature conservation, and human well-being.

\section{Material and Methods}

\section{Study area}

The Brazilian Atlantic Forest (Figure 2) is a biome that originally covered around 150 million ha, encompassing a wide latitudinal, longitudinal, and altitudinal range of the territory. The heterogeneous environmental conditions of precipitation and temperature, for instance, promoted high species diversity and endemism (Rezende et al. 2018). Severe habitat fragmentation threatens the fauna and flora present in this biome (Silva \& Casteleti 2003).

\section{Conceptual model and scenarios}

For our conceptual model, we used a Driver-Pressure-State-ImpactResponse (DPSIR) framework, given its interdisciplinary approach that enables the assessment of the links between economic, social, physical, and biological features of a system (Rousenvell et al. 2010). This framework has been widely applied to demonstrate the causaleffect relationships in human-environmental systems (Rousenvell et al. 2010, Hou et al. 2014) and is considered an effective approach for linking science to policy (Tscherning et al. 2012).

'Driver' refers to a social, demographic and/or economic development leading to 'Pressure' on the environment. Drivers can be distinguished into direct and indirect ones. Indirect drivers derive from demography, economy, policy, culture, religion, science, and technology, and may influence the amount of land that is converted and allocated to food crops, energy crops or urban sprawl (Hou et al. 2014). Direct drivers, in turn, include the land use changes that directly pressure the nature-human systems (Díaz et al. 2015). 'Pressure' is related to emissions of substances, introduction of physical and biological agents, use of resources, and the use of land by human activities that provokes changes on the 'State' of environment. 'State' consists of the physical, biological, and chemical conditions in a specific area. Changes in environment 'State' culminate in 'Impact' on human and environmental systems (e.g., human health, ecosystems, climate, and materials) that may elicit a societal or government 'Response'. 'Response' corresponds to actions and policies which may feed back on the driving forces, pressures, states, or impacts (Smeets \& Weterings 1999, Hou et al. 2014).

The 'impacts' represented in the DPSIR model may have different effects on different stakeholders, depending on who they are and how they value nature. In order to couple those different views into our conceptual model, we described each component of the DPSIR framework and identified its respective connections. Regarding 'impacts', specifically, the components of NFF were attached to express values of nature associated with our case study (i.e., Nature for Nature, Nature for Society, and Nature as Culture).

After creating our conceptual model, we used it to develop the scenarios based on the NFF perspectives. According to each perspective, scenarios were designed to represent the different ways cities can grow and the consequences this could have for the future of biodiversity, ecosystem services and human well-being. In order to do that, we decided to work with the amount and spatial distribution of urban 
Lembi, RC. et al.

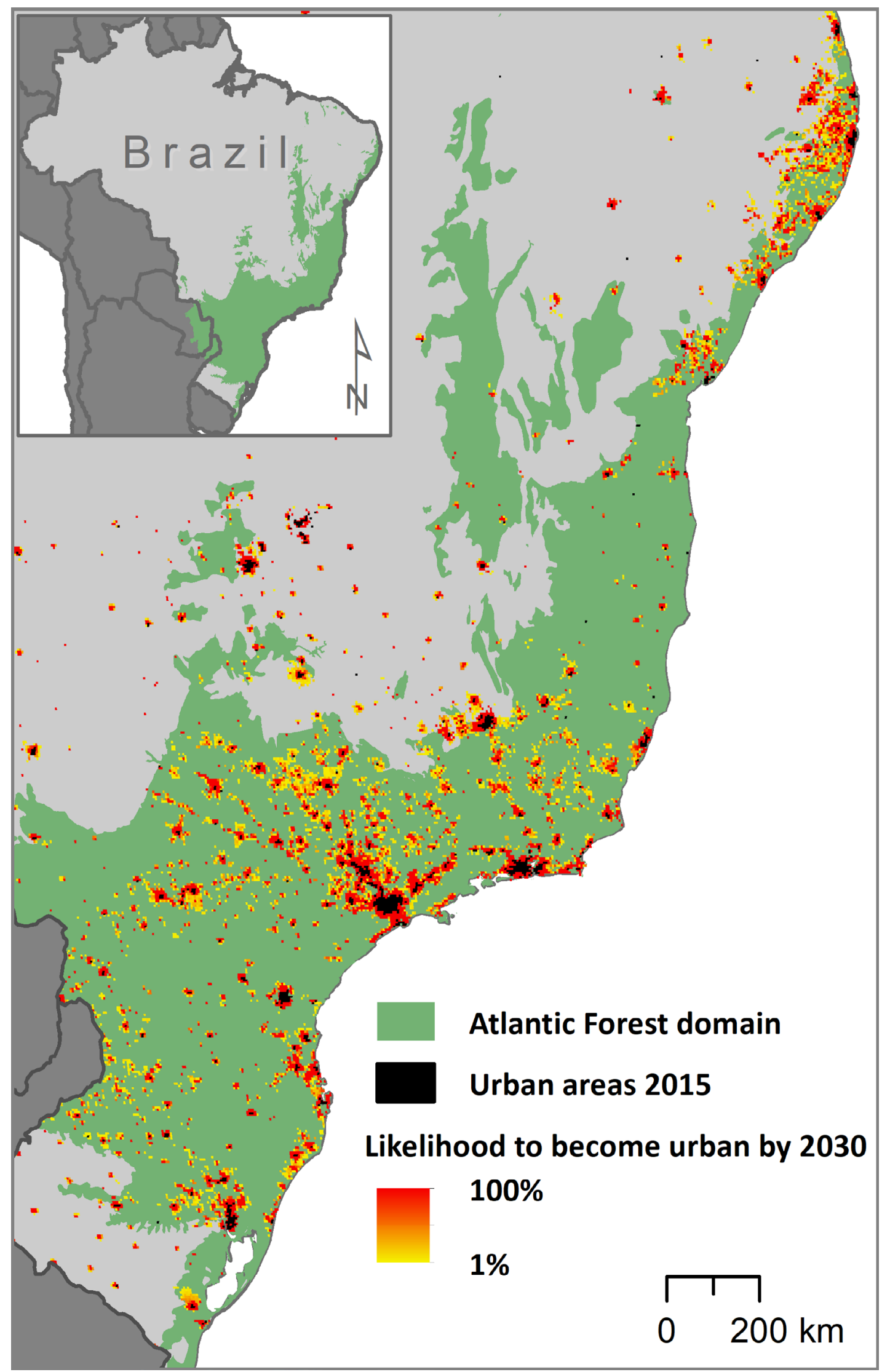

Figure 2. Urban land extent in 2015 and probability of urban expansion by 2030, based on the spatially explicit global forecasts of probability of urban expansion from Seto et al. 2012, in the Atlantic Forest domain in Brazil according to delimitation proposed by Muylaert et al. 2018. Data source: Urban land 2015 (Global Human Settlement Layer, available at https://ghsl.jrc.ec.europa. eu/); Urban expansion (Seto et al. 2016); Atlantic Forest domain (Muylaert et al. 2018). 
green and blue spaces, as well as urban densification policies, and the way these two policies may interact at different scales and affect the connectivity of urban green and blue spaces, and between such spaces and natural habitat fragments at local and regional scales. Urban green and blue spaces are understood here as elements of the green infrastructure, which are a hybrid of built infrastructure and humanmade ecosystems that provide multiple biodiversity and ecosystem services (Kettunen et al. 2014). The scenarios presented here are theoretical and do not represent all the possible ways a city can grow. In accordance with the NFF, only positive scenarios for biodiversity and ecosystem services were represented. We developed our conceptual model using 'draw.io' digital platform and used Inkscape free software (Harrington 2004) to design the future scenarios.

\section{Results}

\section{Conceptual model and Nature Futures Framework}

In our case study, economic and population growth are considered the indirect drivers boosting urban expansion, which is the direct driver. Those drivers are translated into pressures on the environment and we represented these pressures as the loss of natural ecosystems (e.g., primary forests, mangroves, altitude grasslands) linked to the creation and expansion of urban forms. Urban forms refer to the aggregation of spatial patterns of city development such as block size and form, street patterns, lot configuration, parks, and public spaces design (Jabareen 2006). A compact city, for example, aims at increasing the density of inhabitants and recycling spaces within the city instead of expanding its borders (Jabareen 2006).

The loss of natural ecosystems and the increase of urban forms might alter landscape permeability, microclimate, and quantity and quality of the remaining natural ecosystems, as depicted in Figure 3. For our conceptual model, those features were selected as 'states', because changes in them result in impacts on different dimensions of the three perspectives of the NFF. Therefore, such features can be used as a proxy to understand 'impacts' of urban expansion in a multiple value perspective. In the diagram, changes in permeability of the landscape and the quantity and quality of natural ecosystems may impact values across the three NFF perspectives, while changes in microclimate will only affect values of the 'Nature for Nature' and 'Nature for Society' perspectives.

Changes in landscape permeability may affect water supply due to changes in water table rechargeability. A direct impact in cities is the occurrence of floods, which are a critical problem for the cities in the Atlantic Forest, especially during the rainy season. Water quantity and quality in turn are also affected (Pires et al. 2019), since riparian forests are often removed causing soil erosion.

Regarding microclimate alterations, urban expansion is associated with temperature increase and heat island formation in the most urbanized and sealed part of the cities (Cortinovis \& Geneletti 2018), as well as with the loss of green areas inside the cities (Gómez-Baggethun \& Barton 2013). Consequently, higher temperatures can negatively affect citizen's health and well-being, mostly the children and elderly people who are more vulnerable to heat

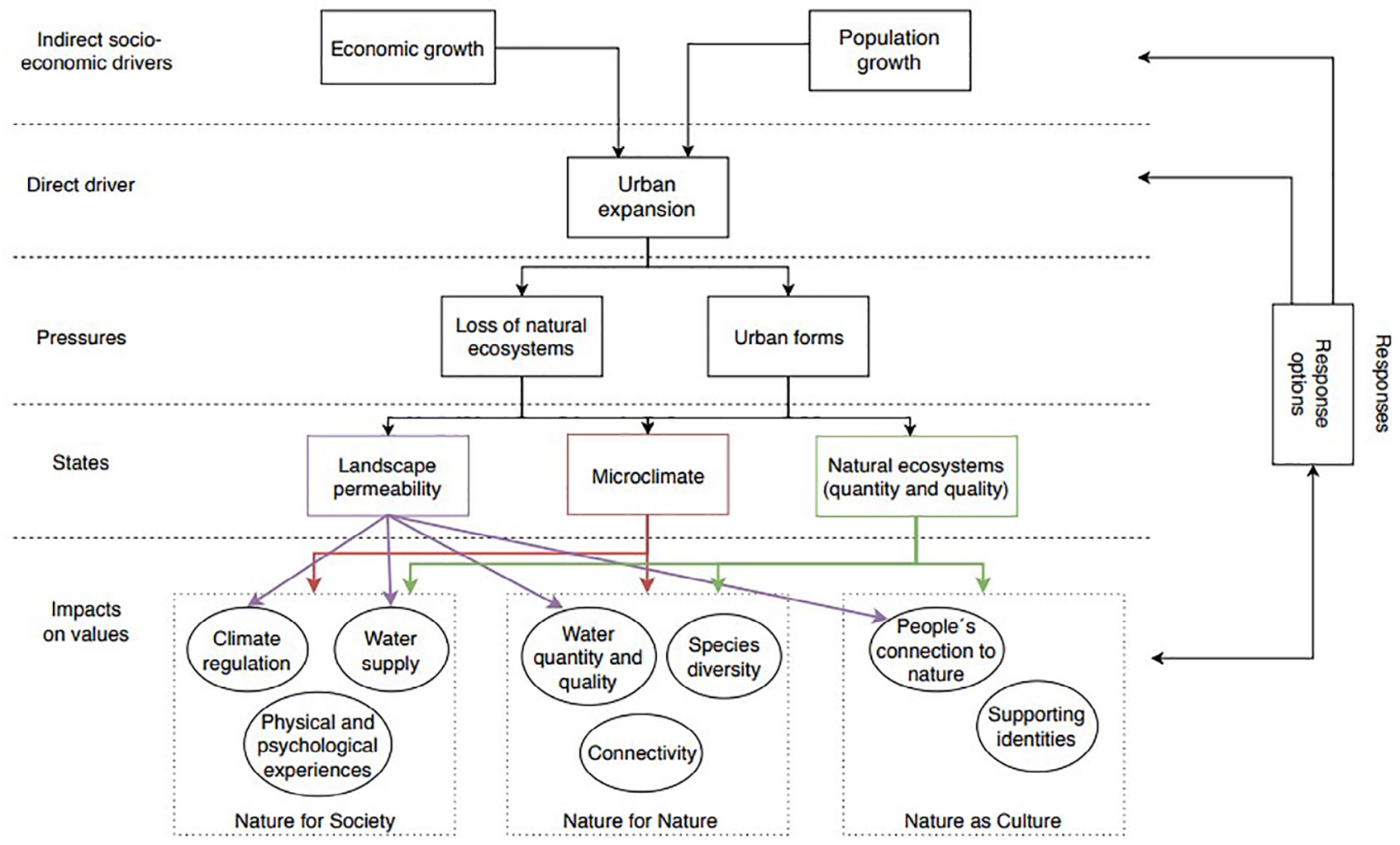

Figure 3. Conceptual model describing drivers and impacts of urban growth in the Atlantic Forest, following the DPSIR approach. Impacts were described for values of nature according to the NFF, which encompasses multiple social-ecological perspectives. 
stress (Cortinovis \& Geneletti 2018). At a larger scale, urban expansion can also increase carbon emissions due to land clearing, reduction in primary productivity, and even higher per capita greenhouse gas emissions, thus contributing to global warming (Seto et al. 2012).

The modifications of quantity and quality of natural ecosystems will potentially impact values across the three NFF perspectives, having effects, for instance, on the amount of available water for human populations, but also for biodiversity (McDonald et al. 2011). The conflict regarding the maintenance of natural ecosystems and the amount and distribution of urban green areas will be a determinant of the available habitat for native biodiversity and how connectivity among remnants will be maintained. The loss of green spaces may also affect the emotional and affective connection that people have with the natural environment (Gómez-Baggethun \& Barton 2013, Chan et al. 2016), as well as may lead to impacts on social and cultural identities of local communities (Sampson \& Goodrich 2009). In this sense, the amount and proximity of urban green and blue spaces available for city dwellers will directly affect people's connection to nature. When taking into account areas outside city limits, natural ecosystems play an important role for the maintenance of a sense of place for some local communities, thus supporting their identities (Masterson et al. 2017). In the context of the Atlantic Forest, those communities can be caiçaras, quilombolas, rural, indigenous people, among others (as established on Federal Decree 6040/07). Therefore, the amount of natural ecosystems, as well as their quality and location, may affect supporting identities.

Finally, impacts on values influence response options in the same way response options influence impacts on values, thereby resulting in feedback mechanisms. Such responses can include statutory regulation and fees, voluntary market-based schemes, spatial and integrated planning, management structures and monitoring, technical arrangements, protected areas, education and knowledge exchange, and private subsidies (Tscherning et al. 2012, Brown \& Everard 2015). Response options can influence socioeconomic driving forces through modifying development and population growth policies.
As mentioned before, one of the main purposes of the DPSIR framework is to connect science to policy. For this reason, the establishment of an indicator set is crucial to represent the causaleffect relationships of DPSIR components. Indicators reflect trends and changes in the environmental-human systems; therefore, they can help inform the formulation of policy targets, and the subsequent tracking of their progress (Smeets \& Weterings 1999, Hou et al. 2014). We propose a set of indicators that could be measured and modeled according to our conceptual model (Table 1). The selection of these indicators took into account their representativeness, data availability (or a proxy), and the geographic scale (local or regional).

\section{Conceptual model to scenarios}

In our conceptual model, the impact on values is expected to produce a feedback acting mainly on the direct driver (Figure 3), which would then promote changes in loss of natural ecosystems and urban forms. This is expected to occur mainly through different response options and here we focus on creation and changes in public policies regarding urban growth and city planning. To compare different strategies that policy makers could implement, we created three scenarios and inferred the impact of the proposed policies on each of the NFF value perspectives (Table 2).

The proposed scenarios feature different ways urban green and blue spaces, connectivity between fragments, and urban densification policies can be planned at both local and regional scales. This framework allows modelling how different urban densification thresholds affect the future size of cities or how different size and spatial distribution patterns of urban green and blue spaces affect microclimate regulation (i.e. heat islands), physical and psychological well-being (through different accessibility to these spaces), and connectivity between urban green and blue spaces and natural habitat fragments.

Scenario 1 focuses primarily on Nature for Society values, and how we can better use urban green and blue spaces to improve biodiversity, ecosystem services and city dwellers' livelihood (Figure 4 - S1).

Table 1. Set of variables and associated indicators regarding the different components of the conceptual model for urban growth in the Atlantic Forest and scales in which they can be measured.

\begin{tabular}{|c|c|c|c|}
\hline & Variable & Indicator & Scale \\
\hline Driver & Urban expansion & Urban area extent & local/regional \\
\hline \multirow[t]{2}{*}{ Pressure } & Loss of natural ecosystems & Area of natural habitat lost & regional \\
\hline & Population density & Number of inhabitants per $\mathrm{m}^{2}$ & local \\
\hline \multirow[t]{10}{*}{ States } & Species diversity & Number of species per pixel & regional \\
\hline & Connectivity & Functional connectivity index & regional \\
\hline & Urban green space & Area of green spaces per person (m2/person) & local \\
\hline & Heat island effect & Temperature range (max/min) & local \\
\hline & & Humidity & local \\
\hline & Drought and floods & Precipitation regime & local \\
\hline & Air quality & Air quality index (PM 2.5) & local \\
\hline & Extreme weather events & Sea level rise & local \\
\hline & & sand/hail storm intensity & local \\
\hline & Water recharge & Percentage of impervious surface & regional \\
\hline \multirow[t]{2}{*}{ Values } & Human well-being & Quantity of green spaces within $300 \mathrm{~m}$ radius & local \\
\hline & & Frequency of mental disorders & local \\
\hline
\end{tabular}


Urban expansion in the Atlantic Forest

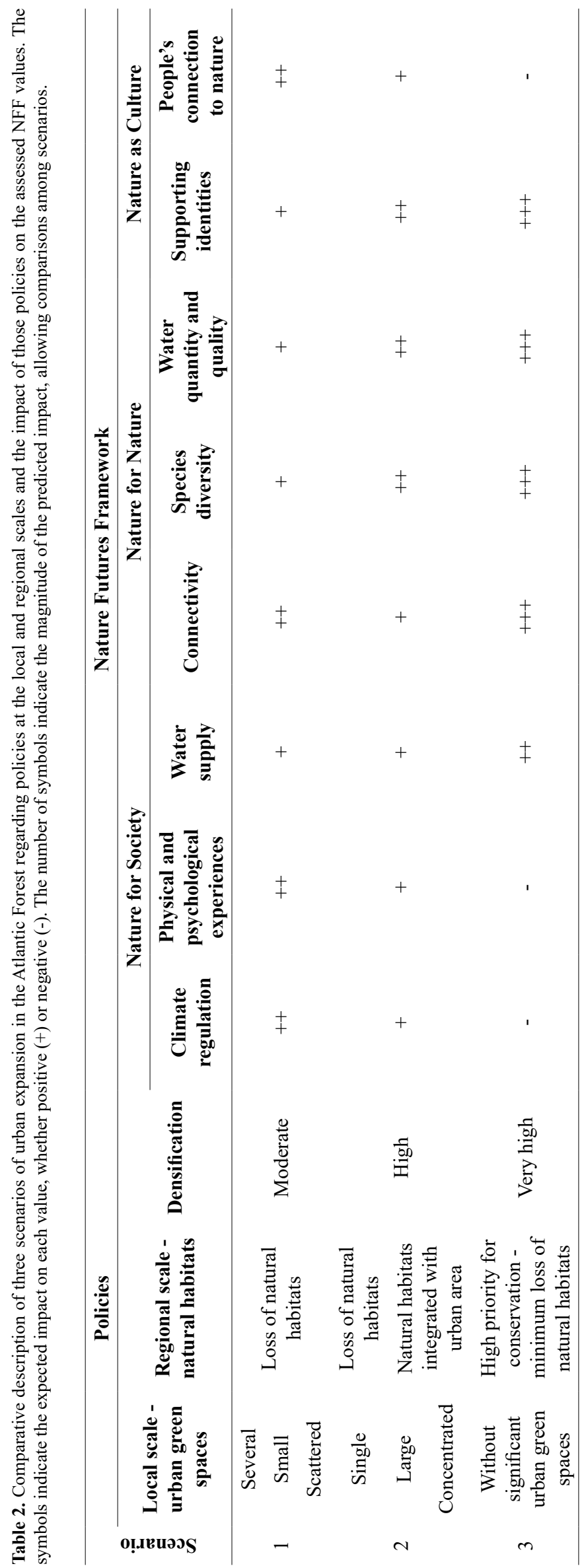


Together with a moderate densification policy, this city planning would also result in urban sprawl and loss of natural habitats. In this scenario, policy regulates the minimum area of green spaces per person (WHO 2012 defines a minimum of $9 \mathrm{~m}^{2}$ per person) and the maximum distance from local residences ( $300 \mathrm{~m}$ is defined as an acceptable distance - WHO Regional Office for Europe 2016). These areas are scattered throughout the city, thereby aiming to maximise access in order to improve non-material ecosystem services such as physical and psychological experiences and people's connection to nature. Spatial distribution of urban green and blue spaces can also influence microclimate regulation through the borders of heat islands and improve connectivity between these areas and other natural habitats on the city outskirts. However, since such spaces are scattered, they become smaller in area, which means they are not able to provide suitable habitat for many species. While urban green and blue spaces would reduce the proportion of impervious surface at the local scale, increasing water rechargeability, the reduction of natural ecosystems at the large scale would result in loss of water-related services, causing an overall positive but moderate effect on water supply and water quantity and quality. This scenario also benefits supporting identities of local communities located outside city limits, by means of providing and maintaining opportunities to develop cultural links to nature. Equity in access to urban green and blue spaces is valued within this scenario, as well as diversity of uses in these areas.

On the other hand, if city planning focuses more on Nature for Nature values, and the main goal is to keep urban biodiversity high, policies could prioritize urban green and blue spaces with larger sizes and good connectivity between these areas and natural habitat outside the city center (Figure 4 - S2). By increasing in area, the number of these spaces would be lower and densification would be higher than in the previous scenario. In Scenario 2, accessibility to urban green and blue spaces is unequal, resulting in an uneven response in physical and psychological experiences and people's connection to nature, favouring city dwellers that live in proximity to them. This inequality could provoke an erosion in the social and cultural link to nature where the loss of green spaces has been most intensified. Microclimate regulation may also be unevenly distributed throughout the city, allowing the creation of heat islands. Although urban expansion would cause loss of natural habitat, large areas of natural ecosystems would still be preserved in this scenario, resulting in an improvement in water supply, water quantity and quality. At a regional scale, the improvement of connectivity can benefit the maintenance of biodiversity as well as local identity of indigenous peoples and traditional communities, especially because large areas of natural ecosystems are maintained.

Scenario 3 also focuses on Nature for Nature values, however only minimal loss of natural ecosystems is allowed (Figure 4 - S3). Urban densification is thus very high, following a compact city model and leaving almost no urban green and blue spaces because of high values of properties. Biodiversity and connectivity between habitat fragments outside the city centers is high, but biodiversity and ecosystem services inside city nuclei are low. Since natural ecosystems are preserved in this scenario, water supply and water quality will be improved, even though inside cities impervious surfaces are dominant. Given the absence of urban green and blue spaces and distance to natural areas, climate regulation, physical and psychological experiences, as well as cultural values are negatively impacted at local scale. On the other hand, this scenario maintains the largest area of natural habitat, thus improving and maintaining the support of identities of people living outside the cities, especially traditional communities. Theoretically, if city patches are of adequate size, built with adequate materials, and green infrastructure is included (e.g., green roofs), there can still be some biodiversity and ecosystem services of microclimate regulation, physical and psychological experiences, and people's connection to nature. However, the tendency is that the inhabitants of the downtown areas would be the most affected by heat islands and the difficulty to access urban green and blue spaces. In this scenario, because the cities are compact, transportation may be more efficient (if emphasis is given to public rather than individual transport) and there may be a lesser impact over microclimate coming from greenhouse gas emissions from vehicles.

\section{Discussion}

Our conceptual model revealed the main relationships between urban growth processes and impacts on biodiversity, ecosystem services and other social-ecological values embedded in the NFF. By coupling the DPSIR model with this innovative framework, we were able to depict how these multiple values interact and identify possible responses to guide urban growth. The comparison of our three scenarios showed potential trade-offs and synergies among values, highlighting the complexity of urban expansion impacts on a biodiversity hotspot. Different policies could be derived from the scenarios, leading to alternative outcomes, depending on the main interests of the public administration, stakeholders, and especially the targeted values. In this regard, we discuss possible policies to build pathways for achieving a sustainable urban expansion, especially by managing natural areas, densification, and urban green and blue spaces. This discussion is focused on the planning of new development areas and the retrofitting adaptation of established urban centers, both at local and regional scales.

For the planning of new development areas in Brazil, a few existing policies are of particular relevance: (i) the city master plans ("Planos Diretores Municipais", first established by Brazilian Federal Constitution of 1988), which are the main instrument to guide city growth; (ii) Ecological-Economic Zonings ("Zoneamento EcológicoEconômico", first established by Federal Law 6938/1981), which refer to state or regional-level planning; (iii) Municipal Atlantic Forest Plans ("Planos Municipais da Mata Atlântica", established by the Federal Law 11428/2006), which are plans for the protection and recovery of Atlantic Forest remnants in local level including inside urban areas (these plans are mandatory to access conservation and restoration funds - Dutra et al. 2013); and (iv) Water Resource Plans ("Planos de Recursos Hídricos", established by the Federal Law 9433/1997), which focus on water resource in three levels: watershed, state, and national. All these instruments consider the division of the territory in zones with different purposes (Lopes et al. 2017). They can complement each other in a way to formally establish and implement urban densification and urban green and blue spaces rules (city master plans), and promote connectivity among natural areas at local (Municipal Atlantic Forest Plans) and regional scale (Ecological-Economical Zonings and Water Resource Plans).

Despite the existence of distinct planning instruments, their implementation is not guaranteed (Pinheiro 2016). In this case, the main challenges are: funding and implementation of the planning instruments, 

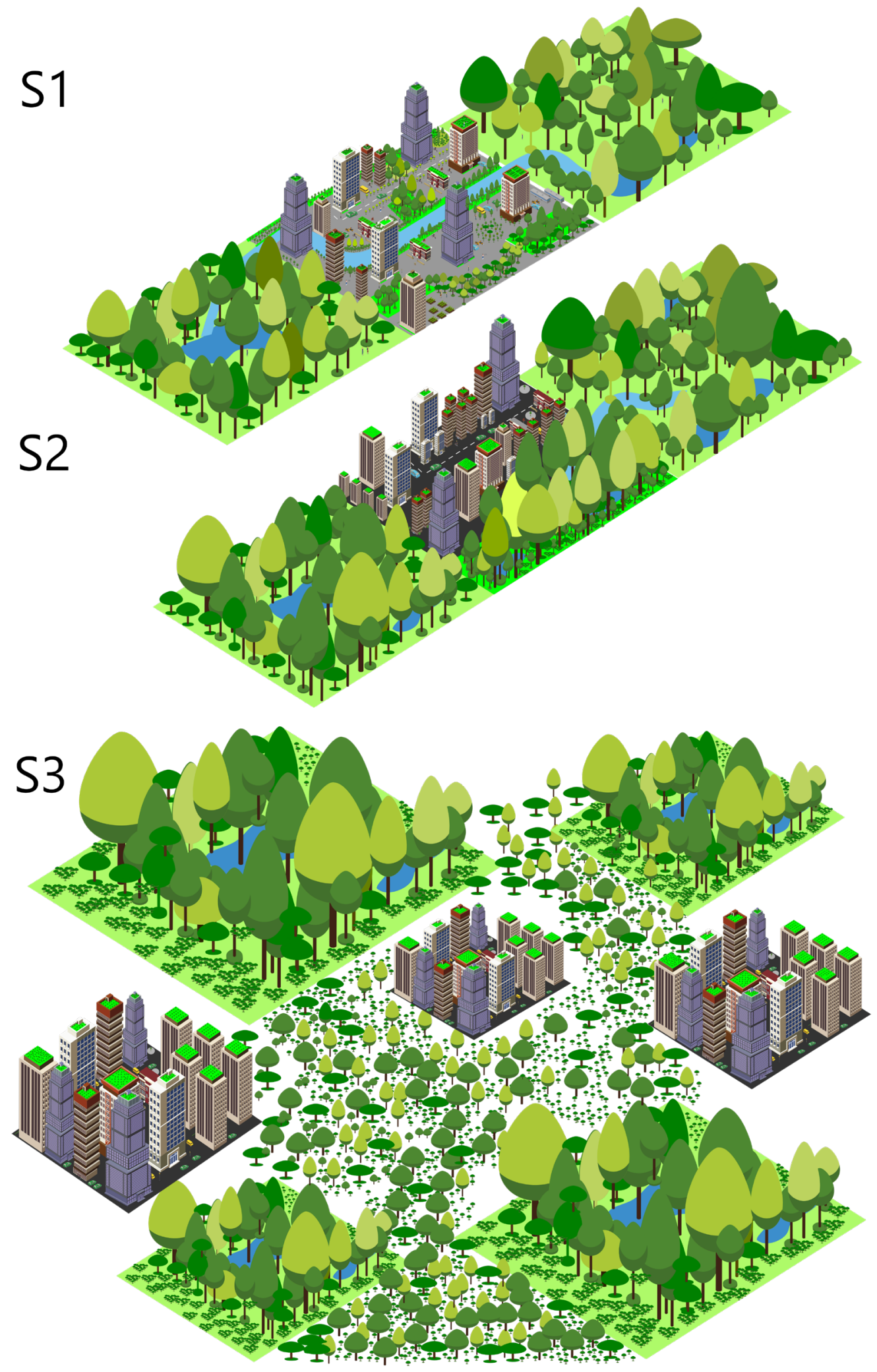

Figure 4. Scenario 1 (S1) - Nature for Society. In this scenario, urban planning prioritizes urban green and blue infrastructure, promoting physical and psychological experiences and increasing people's connection to nature. Scenario 2 (S2) - Nature for Nature. In this scenario, cities grow in a dense way, prioritizing urban green infrastructure, protecting biodiversity by conserving urban forests, and increasing habitat connectivity. Scenario 3 (S3) - Saving land for nature. This scenario is also based on Nature for Nature values, conserving as much forest outside cities as possible and ensuring biodiversity protection. However, biodiversity and ecosystem services inside cities would be low due to a hyperdense cityscape, with almost no urban green and blue infrastructure. 
integration of different plans, and the capacity of the municipalities to offer planned habitation options and urban services versus the high demand created by population growth and migration (Nagendra et al. 2018). Housing needs in Brazil, as in most developing countries, are largely satisfied by informal solutions, such as favelas, which are usually built over, or are adjacent to highly biodiverse ecosystems such as forests or mangroves (Puppin de Oliveira et al. 2011). Although national laws dealing with Ecological-Economical Zonings have been effective since 1981 , the current situation is that only nine out of the 27 Brazilian states have finished their respective planning processes (MMA 2018), and $37,6 \%$ of all Brazilian municipalities that should have a master plan by 2008 , still did not have one in 2015 (IBGE 2016). Moreover, there is no national database that stores all the cities master plans, state and regional Ecological-Economical Zonings, and other plans, making the integration among them a major challenge.

The development of new areas allows the planning of the spatial distribution and area of urban green and blue spaces. However, adapting existing cities poses a different set of challenges. One of these challenges is to promote retrofitting adaptations and to preserve remaining natural habitats with scarce financial investments, especially if we consider that most natural areas that are going to be affected by urban growth are located in countries with moderate to low average incomes (McDonald et al. 2008). For the retrofitting adaptation of established urban centers, policy options include small credit lines or tax compensation to stimulate green roof adaptations, promoting urban gardening, provision of tree saplings for backyards and sidewalks, or greening of vacant lots. Cortinovis \& Geneletti (2018), for instance, discussed alternative scenarios for creating urban parks from regeneration of brownfields and examined the effect of these policies on microclimate regulation and nature-based recreation opportunities. There are some examples of successful city green adaptations around the world, but they are all very costly (Russo \& Cirella 2018) and therefore are not widely applicable. Nevertheless, green solutions for tropical urban centers have been proposed, such as low-cost and low-maintenance green roofs (Silva et al. 2018). Planting trees in cities is also a possible low-cost response option, requiring an annual investment of 8 US dollars per person, on average (McDonald et al. 2017).

Restoration and regeneration strategies are also important to be considered in order to avoid further loss of natural ecosystems, a focal component of our conceptual model. Considering that the area covered by the Atlantic Forest is highly urbanized, natural ecosystems remnants are an important provider of habitat for native biodiversity, enhancing connectivity between fragmented areas. However, planning connectivity between fragments is still a great challenge, since it demands ecological studies of species requirements, investment in a large number of linkages to form corridors (Rudd et al. 2002), and coordinated efforts among multiple municipalities (Seto et al. 2012). Despite those difficulties, connectivity between fragments should be a high priority policy as Atlantic Forest remnants are highly fragmented (Rezende et al. 2018).

Green areas in cities can offer benefits to citizens, including aesthetics and scenic views, a place for socializing and relaxing, and opportunities for physical exercise (Campbell-Arvai 2019, Cortinovis \& Geneletti 2018). Studies have shown associations between the amount of vegetation cover and better outcomes to mental health and well-being such as lower prevalence of anxiety, depression, and life satisfaction and happiness (Cox et al. 2017, Houlden et al. 2019). In this regard, we argue that impaired access to green spaces may be related with depression and nostalgia in individuals. Cultural and social values must be explicitly included in urban green and blue spaces and densification policies, and NFF provides a working framework for this. It is also noteworthy that green areas contribute to microclimate regulation, even though tropical urban environments require a larger extent of green spaces to reduce warming (Manoli et al. 2019).

Another challenge decision-makers face regarding urban policies implementation lies in finding appropriate indicators to express benefits and associated values across the whole range of ecosystem services. For example, the development of indicators for measuring the expected outcomes of planning actions in terms of changes in human well-being and cultural values is still a challenge, often demanding qualitative assessments (Gómez-Baggethun \& Barton 2013). In this regard, the use of our conceptual model, which is a qualitative model, could be the foundation for an evaluation of multiple values regarding urban expansion. A further step would be to develop a quantitative modelling system, and the indicators here proposed could support the development of such models (Table 1). Data on most of these indicators can be obtained either from public databases (e.g. climate variables), scientific literature (e.g. biodiversity) or from local government (e.g. green spaces coverage). However, there are aspects that would require future research, such as the ones related to human well-being and mental health. By translating our model into a more quantitative form, scientists could better inform stakeholders about different pathways to achieve multiple scenarios of urban expansion. The plurality of response options and set of indicators here discussed reveal how different solutions are feasible to address sustainable urban growth in the Atlantic Forest. However, given the complexity of this issue, such policies will only serve the purpose of reconciling conservation, development, and human well-being if designed and applied considering multiple values for nature. As previously stated, people value and acknowledge the services provided by nature and its uses and benefits in different ways, which has implications for environmental management and policies (Gómez-Baggethun \& Barton 2013, Campbell-Arvai 2019). Decisions that take this into account have a better chance of being more sustainable, legitimate, and effective (Jacobs et al. 2016). From a scenarios perspective, not considering such plurality might lead to undesirable futures (Chan et al. 2016). In our case study, the different perspectives that emerged by employing the NFF allowed us to identify synergies between different values. For instance, enhancing urban green and blue spaces seems to be a strategy that is positive to all three NFF's perspectives. For the Nature for Society values, such spaces are important for temperature regulation and recreation opportunities; for Nature for Nature values, they are important for habitat creation and maintenance to support biodiversity; and for Nature as Culture, they serve to promote people's connection to nature and support local identities. Depending on the size, location, and connectivity of the urban green and blue spaces, they may enhance one value more than others, but it is feasible to model a solution that captures the most of the three values for each specific city situation.

Even though the proposed scenarios pose major implementation challenges, they are not far from reality. Sustainable Development Goal 11, proposed by the 193 members of the United Nations, is a commitment to make cities inclusive, safe, resilient, and sustainable (UN 2015). The World Health Organization has recognized the 
importance of urban green and blue spaces in promoting human health (WHO Regional Office for Europe 2017b) and corporations have publicized the benefits of green and blue infrastructure to increase business resilience to external economic and environmental stressors (Dow et al. 2013). Furthermore, the United Nations have declared the period from 2021 to 2030 as the Decade on Ecosystem Restoration, helping to raise awareness and funds towards this issue (UNEP \& FAO 2020).

Regarding this perspective, the use of NFF enabled our conceptual model and scenarios to envision positive futures for nature. Envisioning the future is a difficult task, with inherent associated errors, since the different individual and collective choices are always shaping it on the present. Nevertheless, once a possible scenario is developed, people may act and organise themselves collectively in ways unlikely to happen outside this circumstance, potentially leading to transformative change (Bai et al. 2016). In doing so, the necessary processes to achieve such positive futures can be then discussed, meaning that the creation of new visions for the world can also change how the world currently is (Costanza \& Kubiszewski 2014). However, in order to successfully achieve such world, people should collectively work on a wanted future, shared values, and the plan to achieve this goal (Costanza \& Kubiszewski 2014). This is why urban planning, as well as scenarios development, should be conducted in a participative manner, involving several stakeholders, and considering each city's particularities (geography, demography, budget, priorities, etc). Thus, participatory tools in planning and management of land use can help decision makers to design effective policies, minimizing the risk of competing interests among stakeholders at multiple scales.

Applying the NFF value perspectives can contribute to disentangle complexities and to better understand and navigate urban growth problems, by offering a multiple value perspective that enables the visualization of positive and desirable futures for nature and our world. As Costanza (2003) stated, in order to achieve a better world, we must first envision it. We strongly believe that the integrative and interdisciplinary approach used in this work could lead to better planning and problem-solving of future challenges on urban sustainability in the Brazilian Atlantic Forest.

\section{Acknowledgements}

The authors are thankful to the "São Paulo School of Advanced Science on Scenarios and Modelling on Biodiversity and Ecosystem Services to Support Human Well-Being" organized by BPBES and BIOTA-FAPESP. We thank FAPESP for financial support of SPSAS and travel grants to P.H.A.S. and A.A. Author AVM thanks sDiv for her travel support. We are also thankful to Professor Carlos A. Joly and his entire team for their guidance and facilitation efforts during the programme.

\section{Author contributions}

All authors have contributed in the following aspects:

- Substantial contribution in the concept and design of the study;
- Contribution to data collection;

- Contribution to data analysis and interpretation;

- Contribution to manuscript preparation;

- Contribution to critical revision, adding intellectual content.

\section{Conflicts of interest}

The authors declare that they have no conflict of interest related to the publication of this manuscript.

\section{Ethics}

The authors declare that the study complied with ethical guidelines, and did not require the approval of an ethics committee.

\section{Data availability}

The study does not provide data to be archived in public data repositories.

\section{References}

BAI, X., VAN DER LEEUW, S., O'BRIEN, K., BERKHOUT, F., BIERMANN, F., BRONDIZIO, E. S., CUDENNEC, C., DEARING, J., DURAIAPPAH, A., GLASER, M., REVKIN, A., STEFFEN, W., SYVITSKI, J. 2016. Plausible and desirable futures in the Anthropocene: A new research agenda. Global Environmental Change, 39:351-362.

BERKES, F. \& FOLKE, C. 1998. Linking social and ecological systems for resilience and sustainability. In: Linking Social and Ecological Systems: management practices and social mechanisms for building resilience (F. Berkes \& C. Folke, eds). Cambridge University Press, p.1-25.

BROWN, I. \& EVERARD, M. 2015. A working typology of response options to manage environmental change and their scope for complementarity using an Ecosystem Approach. Environ. Sci. Policy 52:61-73.

CAMPBELL-ARVAI, V. 2019. Engaging urban nature: improving our understanding of public perceptions of the role of biodiversity in cities. Urban Ecosyst. 22:409-423.

CHAN, K.M., BALVANERA, P., BENESSAIAH, K., CHAPMAN, M., DÍAZ, S., GÓMEZ-BAGGETHUN, E., GOULD, R., HANNAHS, N., JAX, K., KLAIN, S., LUCK, G.W., MARTÍN-LÓPEZ, B., MURACA, B., NORTON, B., OTT, K, PASCUAL, U., Satterfield, T., Tadaki, M., Taggart, J. \& Turner, N. 2016. Opinion: Why protect nature? Rethinking values and the environment. P. Natl. Acad. Sci-biol. 113:1462-1465.

CINCOTTA, R.P., WISNEWSKI, J. \& ENGELMAN, R. 2000. Human population in the biodiversity hotspots. Nature 404:990.

CORTINOVIS, C. \& GENELETTI, D. 2018. Mapping and assessing ecosystem services to support urban planning: A case study on brownfield regeneration in Trento, Italy. One Ecosyst. 3: e25477.

COSTANZA, R. 2003. A vision of the future of science: reintegrating the study of humans and the rest of nature. Futures 35:651-314.

COSTANZA, R., KUBISZEWSKI, I. 2014. Why We Need Visions of a Sustainable and Desirable World. In Creating a Sustainable and Desirable Future: Insights from 45 Global Thought Leaders (COSTANZA, R., KUBISZEWSKI, I. eds.) World Scientific, p. 3-8.

COX, D.T.C., SHANAHAN, D.F., HUDSON, H.L., PLUMMER, K.E., SIRIWARDENA, G.M., FULLER, R.A., ANDERSON, K., HANCOCK, S. \& GASTON, K.J. 2017. Doses of neighborhood nature: The benefits for mental health of living with nature. BioScience 67:147-155. 
DAMATA, D., DEICHMANN, U., HENDERSON, J.V, LALL, S.V \& WANG, H.G. 2007. Determinants of city growth in Brazil. J. Urban. Econ. 62:252-272.

DÍAZ, S., DEMISSEW, S., CARABIAS, J., JOLY, C., LONSDALE, M., ASH, N., et al. 2015. The IPBES Conceptual Framework - connecting nature and people. Curr. Opin. Env. Sust. 14:1-16.

DÍAZ, S., PASCUAL, U., STENSEKE, M., MARTÍN-LÓPEZ, B., WATSON, R.T., MOLNÁR, Z., HILL, R., CHAN, K.M.A., BASTE, I.A., BRAUMAN, K.A., POLASKY, S., CHURCH, A., LONSDALE, M., LARIGAUDERIE, A., LEADLEY, P.W., VAN OUDENHOVEN, A.P.E., VAN DER PLAAT, F., SCHRÖTER, M., LAVOREL, S., AUMEERUDDY-THOMAS, Y., BUKVAREVA, E., DAVIES, K., DEMISSEW, S., ERPUL, G., FAILLER, P., GUERRA, C.A., HEWITT, C.L., KEUNE, H., LINDLEY, S. \& SHIRAYAMA, Y. 2018. Assessing nature's contributions to people. Science 359: 270-272.

DITT, E.H., MOURATO, S., GHAZOUL, J. \& KNIGHT, J. 2010. Forest conversion and provision of ecosystem services in the Brazilian Atlantic Forest. Land Degrad. Dev. 21:591-603.

DOW, SWISS RE, SHELL, UNILEVER \& The Nature Conservancy. 2013. The case for green Infrastructure. Joint-industry White paper. Available at: https://www.nature.org/en-us/about-us/who-we-are/how-we-work/workingwith-companies/transforming-business-practices/building-a-case-for-greeninfrastructure/. Last access On 18/09/2019.

DUTRA, C.M., CORDEIRO, S.H.T. DE C., CORDEIRO, L.A. \& DEITENBACH, A. 2013. Roteiro para a elaboração dos Planos Municipais de Conservação e Recuperação da Mata Atlântica. 2 ed. MMA, Brasília.

FAHRIG, L. 2003. Effects of habitat fragmentation on biodiversity. Annu. Rev. Ecol. Evol. S. 34:487-515.

GÓMEZ-BAGGETHUN, E. \& BARTON, D. N. 2013. Classifying and valuing ecosystem services for urban planning. Ecol. Econ. 86:235-245.

GONZÁLEZ-JIMÉNEZ, D., BERGHÖFER, U., BERGHÖFER, A., HEUBACH, K., KOSMUS, M., \& VON BERTRAB-TAMM, A. 2018. Beyond Measurements: Multiple Values of Nature and their Diverse Conceptualization: An introduction for practitioners, based on the IPBES Preliminary Guide on Multiple Values. Available at www.aboutvalues.net. Last access on 10/10/2019.

GÜNERALP, B. \& SETO, K.C. 2013. Futures of global urban expansion: uncertainties and implications for biodiversity conservation. Environ. Res. Lett. 8:014025.

HARRINGTON, B. 2004. Inkscape. Available at http://www.inkscape.org/. Last access on 10/09/2019.

HOU, Y., ZHOU, S., BURKHARD, B. \& MÜLLER, F. 2014. Socioeconomic influences on biodiversity, ecosystem services and human well-being: A quantitative application of the DPSIR model in Jiangsu, China. Sci. Total Environ., 490:1012-1028.

HOULDEN, V., PORTO DE ALBUQUERQUE, J., WEICH, S., \& JARVIS, S. 2019. A spatial analysis of proximate greenspace and mental wellbeing in London. Appl. Geogr. 109:102036.

IBGE - Instituto Brasileiro de Geografia e Estatística. 2016. Pesquisa de informações básicas municipais: Perfil dos Municípios Brasileiros. 2016. Available at https://biblioteca.ibge.gov.br/. Last access on 11/10/2019.

IPBES - Intergovernmental Platform on Biodiversity and Ecosystem Services. 2016. The methodological assessment on scenarios and models of biodiversity and ecosystem services. 2016. FERRIER, S., NINAN, K. N., LEADLEY, P., ALKEMADE, R., ACOSTA, L.A., AKÇAKAYA, H.R., BROTONS, L., CHEUNG, W.W.L., CHRISTENSEN, V., HARHASH, K.A., KABUBO-MARIARA, J., LUNDQUIST, C., OBERSTEINER, M., PEREIRA, H.M., PETERSON, G., PICHS-MADRUGA, R., RAVINDRANATH, N., RONDININI, C. \& WINTLE, B.A. (eds.). Secretariat of the Intergovernmental Science-Policy Platform on Biodiversity and Ecosystem Services, Bonn, Germany. 348 pages.

JABAREEN, Y.R. 2006. Sustainable urban forms: Their typologies, models, and concepts. J. Plan. Educ. Res. 26:38-52.
JACOBS, S., DENDONCKER, N., MARTÍN-LÓPEZ, B., NICHOLAS, D., GOMEZ-BAGGETHUN, E., BOERAEVE, F., MCGRATH, F. L., VIERIKKO, K., GENELETTI, D., SEVECKE, K. J., PIPART, N., PRIMMER, E., MEDERLY, P., SCHMIDT, S., ARAGÃO, A., BARAL, H., BARK, R. H., BRICENO, T., BROGNA, D., CABRAL, P., VRESSE, R., LIQUETE, C., MUELLER, H., PEH, K. S. H., PHELAN, A., RINCÓN, A. R., ROGER, S. H., TURKELBOOM, F., REETH, W. V., ZANTEN, B. T., WAM, H. K., WASHBOURNE, C. L. 2016. A new valuation school: Integrating diverse values of nature in resource and land use decisions. Ecosystem Services, 22:213-220.

JOLY, C.A., METZGER, J.P. \& TABARELLI, M., 2014. Experiences from the Brazilian Atlantic Forest: Ecological findings and conservation initiatives. New Phytol. 204:459-473.

KETTUNEN, M., APOSTOLOPOUlOU, E., BORMPOUDAKIS, D., CENT, J., LETOURNEAU, A., KOIVULEHTO, M., PALONIEMI, R., GRODZIŃSKA-JURCZAK, M., MATHEVET, R., SCOTT, A.V. \& BORGSTRÖM, S. 2014. EU green infrastructure: opportunities and the need for addressing scales. In: Scaling in ecology and biodiversity conservation (K. Henle., S. Potts, W. Kunin, Y. Matsinos, J. Simila, J. Pantis, V. Grobelnik, L. Penev \& J. Settele, eds). Advanced Books. Pensoft, Sofia, Bulgaria.

KRÜGER, E.L., MINELLA, F.O. \& RASIA, F. 2011. Impact of urban geometry on outdoor thermal comfort and air quality from field measurements in Curitiba, Brazil. Build. Environ. 46:621-634.

LOPES, E.R.D.N., SOUZA, J.C. DE, SOUZA, J.A.P. DE, PADOVANNI, N.G., FILHO, J.L.A. \& LOURENCCO, R.W. 2017. Reflexões Sobre O Zoneamento Ecológico- Econômico No Brasil, in: IV Simpósio Brasileiro de Geomática - SBG2017, II Jornadas Lusófonas - Ciências e Tecnologias de Informação Geográfica - CTIG2017. Presidente Prudente, p.155-160.

MANOLI, G., FATICHI, S., SCHLÄPFER, M., YU, K., THOMAS, W., KATUL, G.G. \& BOU-ZEID, E. 2019. Magnitude of urban heat islands largely explained by climate and population. Nature 573:50-60.

MASTERSON, V. A., STEDMAN, R.C., ENQVIST, J., TENGÖ, M., GIUSTI, M., WAHL, D. \& SVEDIN, U. 2017. The contribution of sense of place to social-ecological systems research: a review and research agenda. Ecol. Soc. 22:49.

MCDONALD, R.I., KAREIVA, P. \& FORMAN, R.T. 2008. The implications of current and future urbanization for global protected areas and biodiversity conservation. Biol. Conserv. 141:1695-1703.

MCDONALD, R. I., GREEN, P., BALK, D., FEKETE, B. M., REVENGA, C., TODD, M. \& MONTGOMERY, M. 2011. Urban growth, climate change, and freshwater availability. P. Natl. Acad. Sci. USA. 108:6312-6317.

MCDONALD, R., ALJABAR, L., AUBUCHON, C., BIRNBAUM, H.G., CHANDLER, C., TOOMEY, B., DALEY, J., JIMENEZ, W., TRIESCHMAN, E., PAQUE, J. \& ZEIPER, M. 2017. Funding Trees for Health - An Analysis of Finance and Policy Actions to Enable Tree Planting for Public Health.

MCDONALD, R.I., GÜNERALP, B., HUANG, C.W., SETO, K.C., \& YOU, M. 2018a. Conservation priorities to protect vertebrate endemics from global urban expansion. Biol. Conserv. 224:290-299.

MCDONALD, R.I., COLBERT, M., HAMANN, M., SIMKIN, R. \& WALSH, B. (Eds). 2018b. Nature in the urban century. The Nature Conservancy, p.1-79.

MITCHELL, M.G.E., BENNETT, E.M., GONZALEZ, A. 2014. Forest fragments modulate the provision of multiple ecosystem services. J. Appl. Ecol. 51:909-918.

MMA - MINISTÉRIO DO MEIO AMBIENTE. 2018. Situação do Zoneamento Ecológico-Econômico no Brasil. Available at https://www.mma.gov.br/ images/arquivo/80253/Estados/Informacoes_ZEE_2018_novo.pdf. Last access on $12 / 10 / 2019$.

MUYLAERT, R.L., VANCINE, M.H., BERNARDO, R., OSHIMA, J.E.F., SOBRAL-SOUZA, T., TONETTI, V.R., NIEBUHR, B.B. \& RIBEIRO, M.C. 2018. Uma nota sobre os limites da Mata Atlântica. Oecol. Aust. 22:302-311.

NAGENDRA, H., BAI, X., BRONDIZIO, E. S. \& LWASA, S. 2018. The urban south and the predicament of global sustainability. Nat. Sustain. 1:341. 
PASCUAL, U., BALVANERA, P., DÍAZ, S., PATAKI, G., ROTH, E., STENSEKE, M., WATSON, R.T., DESSANE, E.B., ISLAR, M., KELEMEN, E., MARIS, V., QUAAS, M., SUBRAMANIAN, S.M., WITTMER, H., ADLAN, A., AHN, S., AL-HAFEDH, Y.S., AMANKWAH, E., ASAH, S.T., BERRY, P., BILGIN, A., BRESLOW, S.J., BULLOCK, C., CÁCERES, D., DALY-HASSEN, H., FIGUEROA, E., GOLDEN, C.D., GÓMEZ-BAGGETHUN, E., GONZÁLEZ-JIMÉNEZ, D., HOUDET, J., KEUNE, H., KUMAR, R., MA, K., MAY, P.H., MEAD, A., O'FARRELL, P., PANDIT, R., PENGUE, W. PICHIS-MADRUGA, R., POPA, F., PRESTON, S., PACHECO-BALANZA, D., SAARIKOSKI, H., STRASSBURG, B.B., VAN DEN BELT, M., VERMA, M., WICKSON, F., YAGI, N. 2017. Valuing nature's contributions to people: the IPBES approach. Curr. Opin. Env. Sust. 26:7-16.

PBL - Netherlands Environmental Assessment Agency. 2018. Report on the Workshop 'Next Steps in Developing Nature Futures'. PBL Netherlands Environmental Assessment Agency, The Hague.

PEREIRA, H.M., LEADLEY, P.W., PROENÇA, V., ALKEMADE, R., SCHARLEMANN, J.P.W., FERNANDEZ-MANJARRÉS, J.F., ARAÚJO, M.B., BALVANERA, P., BIGGS, R., CHEUNG, W.W.L., CHINI, L., COOPER, H.D., GILMAN, E.L., GUÉNETTE, S., HURTT, G.C., HUNTINGTON, H.P., MACE, G.M., OBERDOFF, T., REVENGA, C., RODRIGUES, P., SCHOLES, R.J., SUMAILA, U.R. \& WALPOLE, M. 2010. Scenarios for global biodiversity in the 21st century. Science 330:1496-1501.

PINHEIRO, A.I.C. 2016. O Plano Diretor de Curitiba (Lei n 14.771/2015) e sua relação com a função social da propriedade na perspectiva dos direitos urbanísticos e ambiental. Dissertação de Mestrado, Universidade Tecnológica Federal do Paraná, Paraná.

PIRES, A.P.F., FARJALLA, V.F., FARIA, B.M., RODRIGUEZ, D.A., GOMES, E.A.T., SANTOS, E.C., SODRÉ, F.N.G.A.S., SABINO, J., ESPÉCIE, M.A., PINHEIRO, M.R.C., RIBEIRO, M.L., BOZELLI, R.L., PANOSSO, R.F., MORMUL, R.P., BARTHEM, R., SCOFIELD, V. \& DIB, V. 2019. Sumário para Tomadores de Decisão (STD) do Relatório Temático Água: biodiversidade, serviços ecossistêmicos e bem estar humano no Brasil. Editora Cubo, São Carlos. p.1-20.

PUPPIM DE OLIVEIRA, J.A., BALABAN, O., DOLL, C.N.H., MORENOPEÑARANDA, R., GASPARATOS, A., IOSSIFOVA, D. \& SUWA, A. 2011. Cities and biodiversity: Perspectives and governance challenges for implementing the convention on biological diversity (CBD) at the city level. Biol. Conserv. 144:1302-1313.

REZENDE, C.L., SCARANO, F.R., ASSAD, E.D., JOLY, C.A., METZGER, J.P., STRASSBURG, B.B.N., TABARELLI, M., FONSECA, G.A. \& MITTERMEIER, R. A. 2018. From hotspot to hopespot: An opportunity for the Brazilian Atlantic Forest. Persp. Ecol. Conserv. 16:208-214.

ROSA, I. M., PEREIRA, H. M., FERRIER, S., ALKEMADE, R., ACOSTA, L. A., AKCAKAYA, H. R., BELDER, E.D., FAZEL, A.M., FUJIMORI, S., HARFOOT, M., HARHASH, K.A., HARRISON, P.A.,,HAUCK, J., HENDRIKS, R.J.J., HERNÁNDEZ, G., JETZ, W., KARLSSONVINKHUYZEN, S.I., KIM, H., KING, N., KOK, M.T.J., KOLOMYTSEV, G.O., LAZAROVA, T., LEADLEY, P., LUNDQUIST, C.J., MÁRQUEZ, J.G., MEYER, C., NAVARRO, L.M., NESSHÖVER, C., NGO, H.T., NINAN, K.N., PALOMO, M.G., PEREIRA, L.M., PETERSON, G.D., PICHS, R., POPP, A., PURVIS, A., RAVERA, F., RONDININI, C., SATHYAPALAN, J., SCHIPPER, A.M., SEPPELT, R., SETTELE, J., SITAS, N. \& VAN VUUREN, D. 2017. Multiscale scenarios for nature futures. Nat. Ecol. Evol. 1:1416-1419.

ROUNSEVELL, M.D.A., DAWSON, T.P. \& HARRISON, P.A. 2010. A conceptual framework to assess the effects of environmental change on ecosystem services. Biodivers. Conserv. 19:2823-2842.

RUDD, H., VALA, J. \& SCHAEFER, V. 2002. Importance of backyard habitat in a comprehensive biodiversity conservation strategy: a connectivity analysis of urban green spaces. Restor. Ecol. 10:368-375.

RUSSO, A. \& CIRELLA, G.T. 2018. Modern Compact Cities: How Much Greenery Do We Need? Int. J. Env. Res. Pub. He. 15:1-15.

SAMPSON, K.A. \& GOODRICH, C.G. 2009. Making Place: Identity construction and community formation through "Sense of Place" in Westland, New Zealand. Soc. Natur. Resour. 22:901-915.
SETO, K.C., FRAGKIAS, M., GÜNERALP, B., REILLY, M.K. 2011. A MetaAnalysis of Global Urban Land Expansion. PLoS ONE 6:e23777.

SETO, K.C., GÜNERALP, B. \& HUTYRA, L.R. 2012. Global forecasts of urban expansion to 2030 and direct impacts on biodiversity and carbon pools. P. Natl. Acad. Sci-biol. 109:16083-16088.

SETO, K., GÜNERALP, B. \& HUTYRA, L.R. 2016. Global grid of probabilities of urban expansion to 2030. Palisades, NY: NASA socioeconomic data and applications center (SEDAC). https://doi.org/10.7927/h4z899cg. Accessed 26/09/2019.

SILVA, J.M.C. \& CASTELETI, C.H.M. 2003. Status of the biodiversity of the Atlantic Forest of Brazil. In C. Galindo-Leal \& I.G. Câmara (Eds.), The Atlantic Forest of South America: biodiversity status, threats, and outlook (Pp 43-59). Washington, D.C.: CABS and Island Press.

SILVA, B.R., MANTOVANI, A., MANTUANO, D.G., ROLA, S.M., BARBOSA, M.C. 2018. Evaluating Plant Species Suitability for a SubstrateFree Tropical Green Roof. Online J. Biol. Sci. 18:401-423.

SMEETS, E. \& WETERINGS, R. 1999. Environmental indicators: Typology and overview. TNO Centre for Strategy, Technology and Policy, The Netherlands. European Environmental Agency. Technical report, $\mathrm{N}^{\circ} 25$.

TSCHERNING, K., HELMING, K., KRIPPNER, B., SIEBER, S., GOMEZY \& PALOMA, S. 2012. Does research applying the DPSIR framework support decision making? Land Use Policy 29:102-110.

UN - United Nations. 2015. Transforming our world: the 2030 Agenda for Sustainable Development (A/RES/70/1). Available at: https:// sustainabledevelopment.un.org/post2015/transformingourworld/ publication. Last access on 12/09/2019.

UN - United Nations, Department of Economic and Social Affairs, Population Division. 2019. World Urbanization Prospects 2018: Highlights (ST/ESA/ SER.A/421).

UNEP - United Nations Environment Programme \& FAO - Food and Agriculture Organization of the United Nations. 2020. The UN Decade on Ecosystem Restoration 2021-2030: Prevent, halt and reverse the degradation of ecosystems worldwide. Available at: https://wedocs.unep. org/bitstream/handle/20.500.11822/30919/UNDecade.pdf?sequence=7. Last access on 16/01/2020.UNCCD - United Nations Convention to Combat Desertification. 2017. Global land outlook. Bonn, Germany: Secretariat of the United Nations Convention to Combat Desertification.

WHO - World Health Organization. 2012. Health Indicators of Sustainable Cities in the Context of the Rio+20 UN Conference on Sustainable Development. WHO; Geneva, Switzerland.

WHO - World Health Organization. Regional Office for Europe. 2016. Urban green spaces and health. A review of evidence (A.I. Egorov, P. Mudu, M. Braubach \& M. Martuzzi, eds). Copenhagen: WHO Regional Office for Europe, 2016, p.1-81.

WHO - World Health Organization. Regional Office for Europe. 2017a. Urban green spaces: a brief for action. Copenhagen: WHO Regional Office for Europe Available at: http://www.euro.who.int/en/health-topics/environmentand-health/urban-health/publications/2017/urban-green-spaces-a-brief-foraction-2017. Last access on: 03/09/2019.

WHO - World Health Organization. Regional Office for Europe 2017b. Urban green space interventions and health: a review of impacts and effectiveness. Copenhagen: WHO Regional Office for Europe. Available at: http://www. euro.who.int/_data/assets/pdf_file/0010/337690/FULL-REPORT-for-LLP. pdf. Last access on: 03/09/2019. 